\title{
ROLE OF INOVATIVE METHODS IN TEACHING SOCIAL SCIENCE
}

\author{
Prof. Manju Sharma \\ Director, Faculty of Education and Methodology \\ Jayoti Vidhypeeth Women's University. Jaipur \\ Corresponding Email: dean.edu@jvwu.ac.in
}

\begin{abstract}
Introduction: Students from towns and far flung areas come to advanced cities for higher education. This has made the university classrooms a mix of students having a diversity of age, gender, exposure, language, and family backgrounds. To facilitate all these students with personal differences under the same roof, a teacher has to adapt curriculum and lesson plans while bringing innovations in his teaching methods. This study aims to find out the use of innovative strategies by the teachers to respond to students' diversity at higher education level in public and private sector of India. The research is based on the assumption that innovative teaching has a positive impact on the performance of students' diversity.

Methodology: A survey of higher education teachers was conducted for the research. Statistics were applied for the analysis.

Result: The results are found to be significant in favor of innovative teaching. The analysis shows that the use of innovative teaching is more in private sector and also has different impact on different disciplines.
\end{abstract}

Keywords: - innovative teaching, students, diversity, students, performance

\section{INTRODUCTION}

A teacher has to make use of various kinds of methods, devices and techniques of teaching. A teacher has to make use of a suitable method for making his teaching meaningful, purposeful, interesting and effective. A good method of teaching can bring out good results even from a weak curriculum. On the other hand a bad method of teaching can make a mess of a good curriculum. Therefore, it can rightly be said that success or failure of teaching depends on its methods. The methods of teaching should be according to the needs and interests of learners. The biggest challenge for any teacher is capturing each student's attention, and conveying ideas effectively enough to make a long-lasting impression. As an instructor, to tackle this challenge effectively, you ought to implement innovative ideas that build the room expertise far more sweet for your students. School rooms today square measure exemplified by student diversity. the scholars in universities square measure various in numerous aspects like culture, religion, family background, region, and 
colleges wherever they need been finding out (this is incredibly vital in Pakistani scenario). Because of such diversities, students' learning wants also are turning into progressively various. a brand new challenge is to appear for the teaching ways in which will address their wants. to reply to such various wants of the scholars at higher academic levels, totally different innovative teaching and differentiated methods and ways square measure getting used by the academics in their categories.

Characteristics of a decent pedagogics

01. It ought to offer a bunch of connected experiences and activities, organized on a personal yet as cluster basis.

02. It ought to offer scope for the inventive expression of the child's individuality. o It ought to rouse an oversized vary of interest within the minds of the scholars.

03. It ought to shift stress from verbalism and learning to learning through purposeful, concrete and realistic things.

04. It ought to train the scholars within the techniques of self-study and therefore the ways of feat data through personal effort or intuition.

05. It ought to stimulate the will for more study and explorations. o It ought to awaken Associate in Nursing interest within the materials and techniques employed by social scientists

\section{Factors which determine the selection of a teaching method}

1- The nature of the student

2- The objectives of instruction

3- The nature of the subject matter

4- Class room environment

5- Expertise of the teacher who adopts a method

\section{Objectives of the Study}

Do teachers know innovation in teaching social science?

Are teachers using them in teaching social science?

\section{METHOD}

The present study is quantitative in nature. A survey has been conducted to find out the answers of the hypothesis.

\section{Population of the Study}

The target population for the study was the students of public and private schools of Jaipur, the provincial capital of Rajasthan province of India. Jaipur is the capital of Rajasthan. It has renowned private and public education institutions. Students from different regions of India come here to get education.

Sample Size: Two public and two private schools were selected by using stratified random sampling. A sample of 400 
students was taken (100 students from each school).

Research Instrument: A closed-ended questionnaire was developed to conduct the survey. A pilot study was conducted to find out the validity and reliability of the questionnaire.To ensure the validity and reliability of the instrument, the questionnaire was administrated by trained investigators.

Procedure: The data were collected, tabulated, and analyzed for the research purpose. Hierarchal regression was used to test the moderating effect of innovative teaching on the performance of a diverse body of students.

\section{ANALYSIS AND DISCUSSION}

Null Hypotheses 1 and 2

There is no negative relationship between students' diversity and their performance. The innovative teaching of social science is not the moderator between students' diversity and their performance. The diversity of students has a significant effect on the performance of students but this value although negative but has been reduced with the use of innovating teaching methods of social science. Thus, the both hypotheses are rejected. This tells very clearly that if teachers use innovative teaching methods of social science, they can work effectively on students' diversity and will be able to enhance their performance.

Null Hypothesis 3

There is no difference in the use of innovative teaching methods of social science in private and public schools.

The statistical values depict that the innovation is more applied in private-sector universities than the public-sector schools. This rejects the hypothesis and statistically accept the use of innovative strategies more in the private school than the public. It is also pointing toward the contribution and efforts of private sector for the improvement of education. This sector seems more conscious not only about imparting good education but also to meet the diversified needs of students. Null Hypothesis 4

There is no difference in the use of innovative teaching of social science in various disciplines.

The statistical values reject the hypothesis and accept that in different disciplines, different levels of innovative strategies of teaching social science are being used. It has been found that the use of innovative strategies of teaching social science is more and highest in the discipline of humanities through mathematics which has the least value. This may be due to the perception of the teachers of various disciplines. Teachers 
of humanities may find these strategies more effective and easy to use while the mathematics teachers are not aware of such strategies in their subject.

Hypothesis 5

There is no impact of class size on the effect of innovative teaching of social science.

The values shown in the table clearly talk about the impact of class size on the effectiveness of innovation, thus rejecting the hypothesis and agreeing that the class size decreases the effect of innovating strategies of teaching social science. The more the class size, the less will be the impact of innovative teaching.

Impact of Innovative Teaching at Higher Level of Education

Traditional teaching strategies clearly do not meet the needs of students' diversity in a productive way. In a class where lecture is still the centerpiece of instruction and assessment is based on those specific lectures, it provides such an environment which supports learning only at surface level rather than at the dee level (Marton \& Säljö, 1976).The traditional format encourages students to concentrate only on superficial indicators rather than on fundamental underlying principles, thus neglecting deep (active) learning. Active learning refers to experiences in which students have a deep understanding of the subject matter as they interact with the instructors as well as with each other (Gamson, 1991; McKeachie, 1999). Innovative teaching strategies such as active learning refer to a variety of collaborative classroom activities ranging from long-term simulations to 5-min comparative problemsolving exercises (Bonwell \& Eison, 1991; Bonwell \& Sutherland, 1996).

Impact of Innovative Teaching at Higher Level of Education

Traditional teaching strategies clearly do not meet the needs of students' diversity in a productive way. In a class where lecture is still the centerpiece of instruction and assessment is based on those specific lectures, it provides such an environment which supports learning only at surface level rather than at the dee level (Marton \& Säljö, 1976).The traditional format encourages students to concentrate only on superficial indicators rather than on fundamental underlying principles, thus neglecting deep (active) learning. Active learning refers to experiences in which students have a deep understanding of the subject matter as they interact with the instructors as well as with each other (Gamson, 1991; McKeachie, 1999). Innovative teaching strategies such as active 
learning refer to a variety of collaborative classroom activities ranging from long-term simulations to 5-min comparative problemsolving exercises (Bonwell \& Eison, 1991; Bonwell \& Sutherland, 1996).

\section{CONCLUSION}

More students are now in Indian school than ever before, and they are also more diverse than at any time in the past. Students vary in their financial status, social class, family circumstances, and age; their previous educational experience, reasons for attending higher education, and aspirations and ambition; their religion, ethnicity, and nationality; and their abilities, disabilities, and special needs. The innovative strategies need to be implemented and should be modified according to the students' needs.

\section{REFERENCES}

1. Bienzeisler, B., \& Bullinger, H. J. (2007). Innovation und hybride Wertschöpfung. InternationaleZeitschrif

$\mathrm{t}$ für Veränderung, Lernen, Dialog, 13 (1, 2007), 54-58.Google Scholar

2. Blättel-Mink, B. (2006). Kompendium der Innovationsforschung. Wiesbaden: VS Verlag für SozIal wisensch aften. Google Scholar

3. Boes, A., \& Trinks, K. (2007). InternationaleInnovationspartnersch aft en in der IT-Branche. In J. Ludwig, M.
Moldaschl, M. Schmauder, K. Schmierl (Eds.), Arbeitsforschungund Innovation fähigkeit in Deutschland (pp. 85-94), Vol. 9. in: Moldaschl, M., Arbeit, Innovation und Nachhaltigkeit, Munich, Mering: Hampp Verlag.Google Scholar

4. Braun-Thürmann,H.(2005). Innovation. Bielefeld: Transcript Verlag.Google $\underline{\text { Scholar }}$

5. Bruland, K., \& Mowery, D. C. (2005). Innovation through time. In J. Fagerberg, D. C. Mowery, \& R. Nelson (Eds.), The Oxford handbook of innovation (pp. 349-379). Oxford, NY: Oxford University Press.Google $\underline{\text { Scholar }}$

6. Chesbrough, H. W. (2003). Open innovation: The new imperative for creating and profiting from technology.

Boston: Harvard Business School Press.Google Scholar

7. Crozier, M., \& Friedberg, E. (1993). Die Zwänge kollektiven Handelns: Über Macht und Organisation. Frankfurt: Hain. $\underline{\text { Google }}$ $\underline{\text { Scholar }}$

8. Dahrendorf, R. (2009). Nach der Krise: Zurück zur protestantischen Ethik? Sechs Anmerkungen. Merkur, Deutsche Zeitschrift für europäisches Denken, 63 (720, 2009), 373-381.Google Scholar 